$1-2004$

\title{
Undergraduate Summer Research in Structural Engineering
}

Norbert J. Delatte

Cleveland State University, n.delatte@csuohio.edu

Follow this and additional works at: https://engagedscholarship.csuohio.edu/encee_facpub

Part of the Civil Engineering Commons, Engineering Education Commons, and the Structural Engineering Commons

How does access to this work benefit you? Let us know!

\section{Publisher's Statement}

(c) ASCE

\section{Original Citation}

Delatte, N. (2004). "Undergraduate Summer Research in Structural Engineering." J.Prof.Issues

Eng.Educ.Pract., 130(1), 37-43.

This Article is brought to you for free and open access by the Civil and Environmental Engineering at EngagedScholarship@CSU. It has been accepted for inclusion in Civil and Environmental Engineering Faculty Publications by an authorized administrator of EngagedScholarship@CSU. For more information, please contact library.es@csuohio.edu. 


\title{
Undergraduate Summer Research in Structural Engineering
}

\author{
Norbert Delatte, M.ASCE${ }^{1}$
}

\begin{abstract}
For the last seven years, a summer Research Experiences for Undergraduates site in structural engineering, funded by the National Science Foundation, has operated at the University of Alabama at Birmingham. During this time, 33 students from 22 colleges and universities have participated in the site. Participants are recruited nationally and have come from as far away as California and Puerto Rico. The program is intended to provide students interested in graduate studies with an introduction to research methods, and to provide students who will not continue their studies past a bachelor of science in civil engineering with a better understanding of how research provides the theoretical foundation of engineering practice. Students work individually with faculty on literature reviews, computer modeling, laboratory testing, and field research. Three students have researched structural failure case studies and the technical and ethical lessons to be learned from them. Participants also have the opportunity to tour construction sites and construction material manufacturers' and fabricators' facilities. During the past three years, an ethics seminar series has been added. At the end of the program, students prepare research papers and Web pages documenting their work and present their results to faculty, students, and other participants.
\end{abstract}

CE Database subject headings: Undergraduate study; Structural engineering; Research; Engineering education; Universities.

\section{Introduction}

For the last seven years, the University of Alabama at Birmingham (UAB) Department of Civil and Environmental Engineering has hosted a Research Experiences for Undergraduates (REU) site in structural engineering, funded by the National Science Foundation (NSF). During this time, 33 students from 22 colleges and universities have participated in the site. Participants are recruited nationally and have come from as far away as California and Puerto Rico. The nine-week program is conducted on campus during the summer. The students must be U.S. citizens or permanent residents.

Students work directly with structural engineering faculty on projects. Their projects are usually based on ongoing funded research or on faculty interests, although participants may select their own. The projects that the students work on have been supported by the National Cooperative Highway Research Program, the University Transportation Center for Alabama, other agencies, and private industry. Participants are often assisted by graduate students. Participants receive a stipend; students from other institutions also receive travel expenses, meals, and housing.

The program is intended for students who are considering graduate school as well as those who are not. For students considering graduate school, the program provides an introduction to research methods and the opportunity to interact individually with faculty and graduate students. It also gives them the chance to experience and overcome the fear, disorientation, and doubt that are part of undertaking original research. In some cases, the program has also been instrumental in convincing students that graduate school either was or was not for them. The students who continue on to graduate school have greater confidence, stronger research skills, and, in some cases, a project that they can continue to work on.

Students who do not go on to graduate school also realize considerable benefit from the program. Throughout their careers, engineers use building codes and design procedures that are the products of research. If they have undertaken their own research, they are in a better position to understand the strengths and limitations of these codes and procedures. It is important for engineers to engage in lifelong learning, and this program reinforces this importance and provides skills for continued inquiry.

Teller and Gates (2001) have documented some of the benefits of undergraduate research. They pointed out that "the student research experience can

- Increase the probability that students will perform well in science and engineering classes,

- Retain students who may otherwise drop out of college,

- Strengthen student decisions with respect to their declared majors,

- Improve students' confidence,

- Cause students to consider graduate school, and

- Improve students' technical, research, team, communication, problem-solving, and higher level thinking skills, making them more attractive to employers."

A similar program at the University of Nebraska, involving only students from that institution, has been successful in using undergraduate research to attract students to graduate school. It was found that approximately one-third of the undergraduate students who participated in the program remained at the home institution for graduate school. Personal interaction with a faculty member was considered to be an important factor (Narayanan 1999).

In Fiscal Year 2002, the NSF Directorate for Engineering listed 47 active REU sites (http://www.nsf.gov/home/crssprgm/ 
Site title and theme

REU site: Summer research experiences for undergraduate students in construction

REU site: Research experiences for undergraduates program in water research at Colorado State University

Tomography in civil and environmental engineering

Research experiences in pollution prevention

REU site in structural engineering: Development of enhanced materials and structural assemblages used for seismic

performance evaluation studies

Undergraduate research in environmental engineering focused on protection and treatment of water supplies

Undergraduate research experiences in advanced engineered wood composites

Research experiences for undergraduates in civil engineering

Research experiences for undergraduates in geo-environmental systems

Structural engineering research experiences for undergraduates

Research experiences for undergraduates in construction engineering and management
University, college/school or department, and Web site

Arizona State University College of Engineering and Applied Science,

http://construction.asu.edu/reu

Colorado State University Civil Engineering Department,

http://waterreu.colostate.edu/

Louisiana State University Department of Civil and Environmental

Engineering, http://www.ce.lsu.edu/ reu/

Rowan University Department of Civil and Environmental Engineering, http://sun00.rowan.edu/ everett/reu/ReuFrst.htm

University of Cincinnati School of Civil Engineering and Environmental

Science, http://www.eng.uc.edu/dept_cee/undergrad/research

University of Colorado-Boulder Department of Civil, Environmental, and Architectural Engineering, http://civil.colorado.edu/ silverst/reu.html University of Maine Department of Civil and Environmental Engineering, http://www.umeciv.maine.edu/reu/

University of New Mexico Department of Civil Engineering,

http://www.unm.edu/ censfreu

University of Oklahoma School of Civil Engineering and Environmental

Science, http://www.ou.edu/cees

Washington University Department of Civil Engineering, http://wusceel.cive.wustl.edu/reu/

Western Michigan University Construction Engineering/Materials

Engineering/Industrial Design,

http://www.wmich.edu/nsfrev reu/reu98eng.htm). Of these, 12, including the UAB site, have a focus in civil or environmental engineering or construction. These sites are listed in Table 1. Many of them have a similar structure to the UAB site. Only Washington University in St. Louis has a focus identical to that of the UAB site, although the University of Cincinnati and University of Maine sites address specific topics within structural engineering. In addition to the sites in engineering, the NSF supports sites in astronomical sciences, atmospheric sciences, biological sciences, chemistry, computer and information science and engineering, earth sciences, mathematical sciences, materials research, materials research science and engineering centers, ocean sciences, physics, and social, behavioral, and economic research.

Mervis (2001) discussed a wide range of undergraduate research experiences and made the following observations:

- Considerable variation exists among programs.

- There is little agreement on how programs should be structured or evaluated, although most programs consider themselves successful.

- A few schools, mostly small colleges, require an individual research project for graduation.

This author also notes that coaching undergraduates through a research experience requires a considerable investment of time and effort from the faculty, pointing out that at one small college that requires undergraduate research "many faculty members seem to view it as more of a burden than a benefit" (Mervis 2001, p. 1615).

González (2001, p. 1624) reviewed the link between undergraduate research and graduate mentoring and their importance to the university's mission, noting that "they both speak to the primary mission of the research university, which is not carrying out research but training students to do research." She suggests that lower division and upper division undergraduate research has an important place in a continuum that starts at those levels and continues through master's, doctoral, and postdoctoral research.

This paper will review the writer's experience with the UAB site and discuss the program objectives, how the participants are recruited, how the program is carried out, the student research products, and the results of the program evaluation. Some of the lessons learned in the conduct of this program are also documented.

\section{Program Objectives}

The NSF REU program provides support for a large number of sites at various universities, with a variety of research focus areas. The objectives of the site discussed in this paper are

- To provide an introduction to research topics and methods,

- To provide students with the skills and confidence needed to conduct original research,

- To allow students to achieve the satisfaction of completing an individual research project, including oral, written, and Web presentation of results,

- To introduce students to ethical issues in structural engineering research and practice,

- To develop a collaborative learning environment between the participants, faculty, and graduate students,

- To produce papers that may be published in peer-reviewed technical journals, and

- To recruit students to graduate school (master's and/or doctoral) and specifically the UAB graduate program.

These are ambitious objectives, and not all have been completely achieved. The last two have proven to be particularly challenging. 


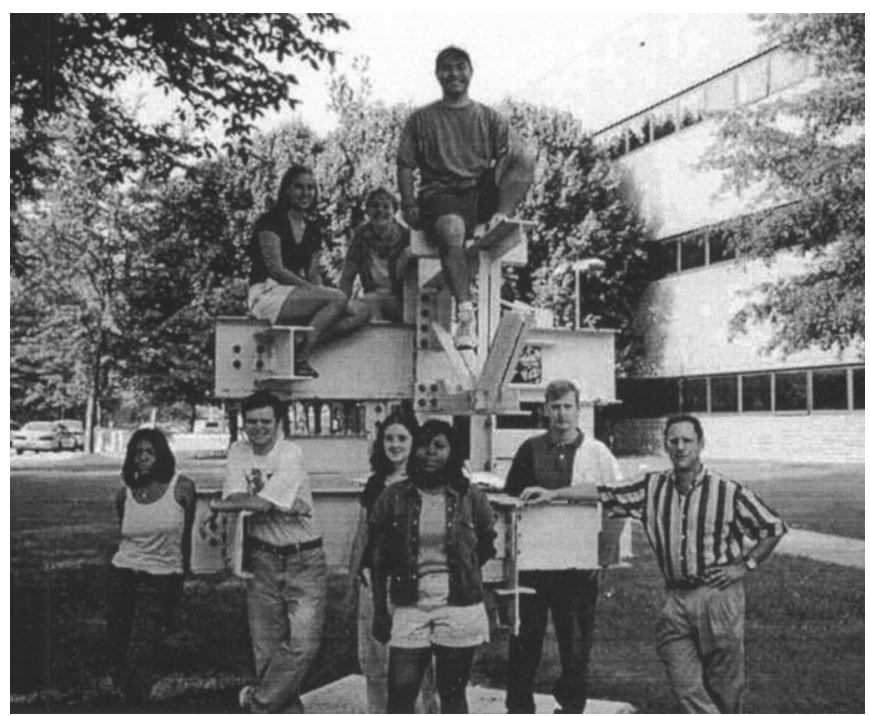

Fig. 1. Summer 1999 UAB REU program participants

\section{Recruiting}

The cornerstone of the program is recruiting a group of students who will benefit from as well as contribute to the program. It is important to provide a good mix of students who complement each other in background and experience. The writer mails posters and application forms to faculty at other institutions. Usually at least 50 packets are mailed each year, and the total mailing list has now increased to 75 . This is supplemented by personal contacts and phone calls. The writer makes it a point to discuss the site with colleagues at technical conferences. Students may also apply over the Web site at http://www.eng.uab.edu/cee/REU NSF99/reumain.htm. A large number of inquiries each year come directly from the NSF REU Web site, which provides contact information for all active sites. Most of the REU sites listed in Table 1 provide application instructions at their Web sites.

Student transcripts, letters of recommendation, and essays are considered during the application process. However, the writer's experience is that these factors are not always good predictors of student success in the program, because applicants rarely have prior experience conducting original research. Often, students with marginal or average academic records do very well in the program. They may also be the students who benefit the most from the experience, by building their confidence in their chosen profession. Other students function very well in a structured classroom setting, but find themselves lost when forced to take responsibility for their own education.

Selections are made by a committee of the structural engineering faculty that will be hosting the students. The committee emphasizes geographic, ethnic, and gender diversity. It is important to consider students from schools that do not have graduate programs, because these students often have few other research opportunities. The summer of 1999 participants are shown with the writer in Fig. 1. Most of the students who have participated in the program have been civil engineering majors, although a few physics majors have been included.

\section{Summer Program}

Participants arrive in early June. Over the next nine weeks, the students spend 40 hours per week in seminars, on tours, and
Table 2. Selected Research Areas and Projects, 1999-2001

\begin{tabular}{|c|c|}
\hline Research area & Project and year \\
\hline Curved steel bridges & $\begin{array}{l}\text { "Girder flange and cross-frame members } \\
\text { earthquake induced stresses," } 1999 \\
\text { "Dilemmas in the construction of steel curved } \\
\text { bridges," } 1999\end{array}$ \\
\hline Failure case studies & $\begin{array}{l}\text { "Failure case studies in civil engineering } \\
\text { education," } 1999 \\
\text { "Failure case studies in civil engineering," 200 } \\
\text { "Collapse of } 2000 \text { Commonwealth Avenue: } \\
\text { A case study," } 2001\end{array}$ \\
\hline $\begin{array}{l}\text { Sign, signal, and } \\
\text { luminaire support } \\
\text { structures }\end{array}$ & $\begin{array}{l}\text { "Computer-aided design of support structures," } \\
1999 \\
\text { "Improving analysis of wind forces on flexible } \\
\text { support structures," } 2000\end{array}$ \\
\hline $\begin{array}{l}\text { Aerated autoclaved } \\
\text { concrete }\end{array}$ & $\begin{array}{l}\text { "Laboratory studies of advanced cementitious } \\
\text { materials," } 1999 \\
\text { "Shear testing of AAC," } 2000\end{array}$ \\
\hline $\begin{array}{l}\text { Structural response } \\
\text { to blast }\end{array}$ & $\begin{array}{l}\text { "Blast response of retrofitted concrete } \\
\text { structures," } 1999 \\
\text { "Blast response of masonry and reinforced } \\
\text { concrete structures," } 2000\end{array}$ \\
\hline $\begin{array}{l}\text { Concrete } \\
\text { performance } \\
\text { and durability }\end{array}$ & $\begin{array}{l}\text { "Supplementary cementitious materials to } \\
\text { enhance durability of concrete bridge decks," } \\
2000 \\
\text { "Chloride permeability of bottom ash } \\
\text { concrete," } 2001 \\
\text { "Design and quality control of concrete } \\
\text { overlays and repairs," } 2001\end{array}$ \\
\hline $\begin{array}{l}\text { Nondestructive } \\
\text { testing }\end{array}$ & $\begin{array}{l}\text { "Comparing geological profile and SASW } \\
\text { results in Alabama," } 2000 \\
\text { "Correlating soil stiffness using SPT and } \\
\text { SASW," } 2000 \\
\text { "Construction of subsurface soil profiles: } \\
\text { A case study in SASW testing," } 2001 \\
\text { "Bridge dynamics," } 2001\end{array}$ \\
\hline
\end{tabular}

working on their projects. An initial set of orientation meetings is held. Later in the week, the students begin to meet individually with faculty to start work on their projects.

Because of the short duration of the program, it is important to get students started quickly on their projects. It is also important for the faculty to select projects that are achievable within this time frame, but that will also represent a significant accomplishment for the students. Project selection remains a difficult challenge for faculty, but gets easier with experience. A selection of research focus areas along with project titles is provided in Table 2. Some projects are offered only one year, and others are repeated.

With the exception of one project in the summer of 2000 , students have worked individually. In the summer of 2000, two students worked together on a project that involved considerable laboratory testing. This gave the faculty an opportunity to investigate whether that would be a better way for students working on labor-intensive laboratory projects. Teller and Gates (2001) have had success with group projects.

A successful project topic should meet a number of criteria.

- It should address an area of interest and expertise for one of the participating faculty, typically either funded research or a new focus area requiring exploratory investigation. 
- It should be appropriate to the student's background, skill level, and interests.

- It should be possible to perform background research, perform the study, and prepare a report within nine weeks.

Typically, each of the participating faculty is assigned one to three students, depending on available ongoing projects and, more important, available time for the summer. Next, the writer and other faculty develop a preliminary list of projects that will be refined during meetings between the faculty and participants during the first week of the program.

\section{Orientation}

To make the students welcome, they are generally met on arrival by the writer or another faculty member. A luncheon is held to introduce the host campus faculty, staff, and students to the participants. Next, a tour of department facilities and laboratories is provided, along with laboratory safety training and documentation of that training. The students also receive a tour of campus facilities. During the first week, they are issued research supplies and computer accounts. Several computers have been obtained specifically to support this program. The students have full access to PC and Unix computation resources. It is helpful during the orientation period to have host campus students as program participants.

\section{Research Seminars}

A series of seminars provides an introduction to research methods and available resources. The School of Engineering librarian provides an orientation to library facilities and computer searches. Participants are provided with library cards and copy cards, and may request interlibrary loan materials through their faculty advisors.

Weekly progress meetings are held so that the participants can review progress to date and discuss planned work and potential obstacles. As needed, seminars are scheduled on other topics, such as Web page software, presentation software, and the use of other software packages.

\section{Ethics Seminars}

When the UAB REU site was renewed in 1999, an ethics program was added. This program has two components. Each year, one student project concerns ethical issues in structural engineering education and practice, and lessons learned from failures. These are the projects listed as "failure case studies" in Table 2. An ethics seminar series is also included. The writer is assisted in this seminar series by Dr. Harold Kincaid, a professor in the UAB Department of Philosophy and director of the Center for the Study of Ethics and Values in the Sciences. Typical ethics seminars include

- Viewing of the film "When Engineering Fails," narrated by Henry Petroski, followed by a group discussion,

- A discussion of ethical issues in scientific research (these include well-known scientific fraud cases and issues of proper attribution of work),

- Small-group discussions of ethics in professional practice, using case studies from the University of Washington Ethics Case of the Month Web site (http://www.engr.washington.edu/ uw-epp/Pepl/Ethics/),

- A discussion on professional licensure issues led by a guest speaker from the Alabama Licensing Board (this also provided

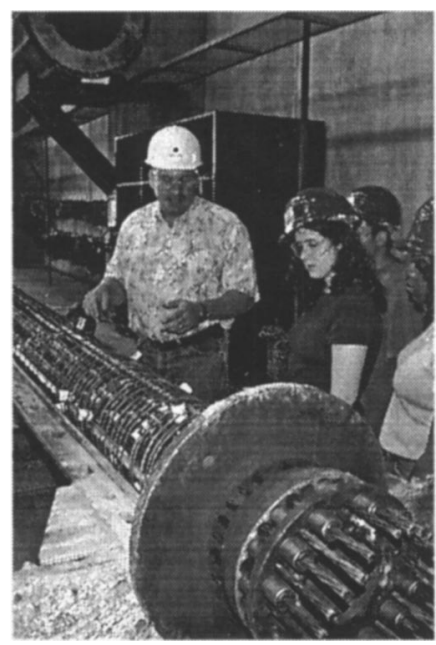

Fig. 2. Summer 1999 REU students tour Newmark prestressed spun concrete pole facility in Tuscaloosa, Ala.

an opportunity for students to ask questions about the Fundamentals of Engineering examination and Professional Engineer licensure),

- A discussion of the William LeMessurier Citicorp Tower case, and the importance of calling attention to and fixing your mistakes, and

- Discussion of case studies prepared by the UAB REU students.

\section{Tours and Field Trips}

Since 1999, participants have taken three or four tours each summer to manufacturing facilities or construction sites. Manufacturing facility tours have included

- Sherman International Corporation precast and prestressed concrete facility in Pelham, Ala., which manufactures bridge girders and other products,

- Wal-Par, Inc. steel structure manufacturing facility in Birmingham, which primarily manufactures sign support structures,

- Newmark Infrastructure Solutions prestressed spun concrete pole facility in Tuscaloosa, Ala. (Fig. 2),

- Vulcan Materials Company Dulcito Quarry in Birmingham, a producer of construction aggregates,

- Lehigh Cement manufacturing facility in Leeds, Ala., and

- Butler Manufacturing preengineered metal building manufacturing facility.

Construction site tours have included several buildings under construction on the UAB campus, such as the

- Human Genetics Building and

- New student dormitory building.

\section{Student Publications and Presentations}

The presentation of student results is an important aspect of the program. Each student prepares a Web page, a presentation, and a research paper. The students spend considerable time and effort on these products, which are made available from the Web site. All of the REU sites listed in Table 1 also have Web sites, most of which also provide some research results. 


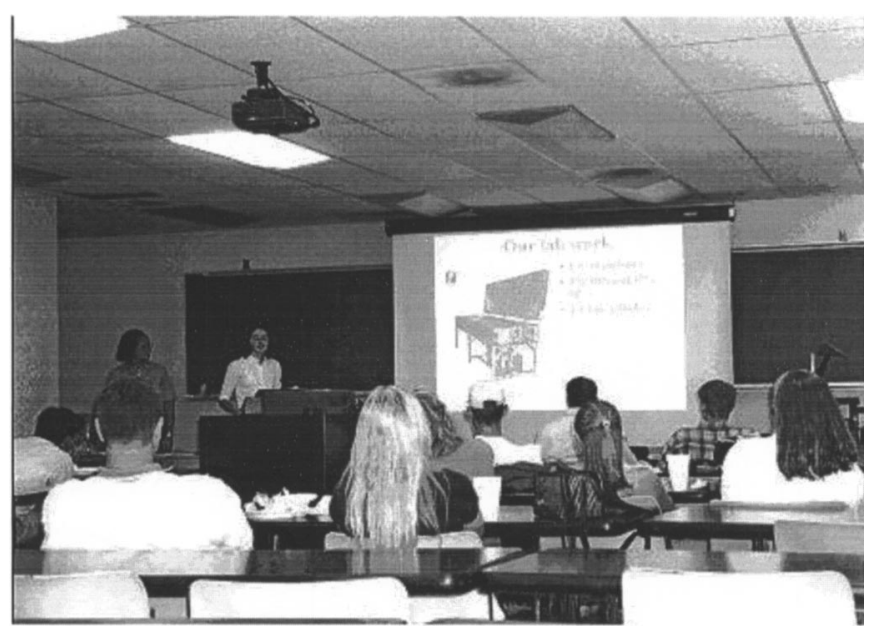

Fig. 3. Two students jointly present their results, summer 2000

\section{Web Pages}

The student Web pages link from the main REU Web page, listed by year. In addition to documenting the student work, these give students interested in applying for the program an idea of what sort of projects are available. Typically, when prospective participants inquire about available projects, the writer directs them to the Web site for examples. Some students choose to build on previous work.

The Web pages usually contain the following information:

- Project description and results,

- Link to home university (for non-UAB students),

- Personal information (optional), and

- Research project papers and presentations as portable document format files.

These have also proven to be useful to the students in their job searches. A potential employer contacted the writer for a reference on one participant; the writer provided it, and provided a link to the Web site. In a follow-up message, the employer noted that he had reviewed another student's Web page and planned to contact that student about another position. Many of the REU Web sites listed in Table 1 also provide individual participant Web pages.

\section{Final Presentations}

All participants make a final presentation to faculty, staff, and students. The $2 \mathrm{~h}$ presentation session is scheduled a few days before the end of the program. Presentations are limited to 10 min. Two students from the summer of 2000 program making a joint presentation are shown in Fig. 3. The final presentations are usually added to the student Web sites. Four of the Web sites listed in Table 1 provide copies of participants' final presentations.

\section{Proceedings and Student Papers}

For the past two years, the student research papers have been collected and bound in an annual proceedings volume. It was found necessary to limit student papers to 30 pages, since some wanted to write longer papers. Needless to say, this was not a problem that the writer had anticipated. Each student and faculty advisor receives a copy, and a copy is placed in the home campus library. A review of the REU Web sites listed in Table 1 indicates that only the Washington University in St. Louis site provides papers on-line, although most of the others provide a project abstract.

\section{Other Publications}

This program is most valuable for students and faculty in the long term, when it produces peer-reviewed publications. Rachel Martin's work in 1999 resulted in two papers published in the ASCE Journal of Performance of Constructed Facilities (Martin and Delatte 2000, 2001). Her work was also used in a paper presented at the ASCE 2nd Forensics Congress (Delatte 2000). Other student work has been incorporated into research reports and publications. The writer is currently drafting a paper based on a 2001 participant's failure case study.

\section{Program Evaluation}

Each year, participants are asked to evaluate the program in order to improve it. The program participants are surveyed on arrival, on departure, and approximately six months after leaving. Survey questions on a five-point scale $(1=$ low to $5=$ high $)$ and 19992001 results are shown in Table 3. The change indicates the difference between the incoming survey filled out by students on the first day of the program, and the final (end-of-program) survey filled out at the end, with a positive number indicating that the average response increased during the program.

The survey results indicate that the students have strong confidence in their abilities to complete their undergraduate programs. This is not affected much by the program. Most students recruited for the program are capable and well committed to their undergraduate degree programs.

Results on encouraging students to continue on for a master of science degree are mixed. Although the survey is anonymous, there is some indication that there is a rough balance between students who had planned to continue on to graduate school, and decide not to, and those who had not planned to continue, but change their minds. Therefore, although the program may not be bringing more students into graduate school, it may be helping the right students identify themselves. It should be noted that these years cover a time when many engineering graduates could count on receiving many attractive job offers, making graduate study less enticing. In the present cooling economy, this may change.

The desire to continue on for a doctorate degree decreased slightly. This tendency was low to begin with, and the small number of students expressing a desire to study for a doctorate at the beginning of the program may not have realized the level of effort involved before undertaking their own independent research.

On the other hand, research skills and recognition of their importance went up significantly, as did the confidence of the participants. The positive responses to Survey Questions 5, 6, and 7 are heartening, since this is the main focus of the program.

The understanding of the importance of ethics also increased, with respect to both research and professional practice. Overall, the students saw the value of the ethics component of the REU site. The already high tendency for students to take the Fundamentals of Engineering examination was essentially unchanged, although one student who was not an engineering major may have skewed the 2001 result.

The survey results indicate that the program is successful in introducing students to research and ethics and their importance, but less successful in enticing them to continue on to graduate 


\begin{tabular}{|c|c|c|c|c|c|c|}
\hline \multirow[b]{2}{*}{ Questions } & \multicolumn{2}{|c|}{1999} & \multicolumn{2}{|c|}{2000} & \multicolumn{2}{|c|}{2001} \\
\hline & After & Change & After & Change & After & Change \\
\hline 1. I am capable of completing my undergraduate degree. & 5.00 & 0.00 & 5.00 & 0.00 & 4.86 & -0.14 \\
\hline 2. I intend to complete my undergraduate degree. & 5.00 & 0.00 & 5.00 & 0.13 & 5.00 & 0.00 \\
\hline $\begin{array}{l}\text { 3. I intend to attempt to complete a Master of Science degree in structural } \\
\text { engineering or a closely related discipline. }\end{array}$ & 3.25 & -0.13 & 4.63 & 0.75 & 3.71 & -0.41 \\
\hline $\begin{array}{l}\text { 4. I intend to attempt to complete a Doctor of Philosophy degree in } \\
\text { structural engineering or a closely related discipline. }\end{array}$ & 1.38 & -0.13 & 2.50 & -0.50 & 2.00 & -0.75 \\
\hline $\begin{array}{l}\text { 5. Knowing how to conduct, document, and interpret research is important } \\
\text { for a practicing engineer. }\end{array}$ & 4.63 & 0.38 & 4.75 & 0.13 & 4.57 & 0.07 \\
\hline 6. I can plan and complete a research project and report the results. & 4.25 & 0.25 & 4.63 & 0.38 & 3.86 & -0.02 \\
\hline 7. I can conduct a thorough literature review of a topic. & 4.50 & 0.63 & 4.75 & 0.75 & 4.14 & 0.39 \\
\hline 8. Research must be conducted ethically. & 4.88 & 0.13 & 4.88 & 0.25 & 4.86 & 0.23 \\
\hline 9. Practicing engineers must always maintain high ethical standards. & 5.00 & 0.50 & 4.88 & 0.13 & 4.86 & 0.23 \\
\hline 10. I intend to take the Fundamentals of Engineering exam. & 4.50 & 0.25 & 4.88 & 0.00 & 4.14 & -0.11 \\
\hline 11. The ethics part of this REU was very useful and important. & 4.00 & $-^{\mathrm{a}}$ & 3.88 & $-^{\mathrm{a}}$ & 3.86 & $-^{\mathrm{a}}$ \\
\hline
\end{tabular}

Note: Concerning the scale, students were asked, "Please indicate whether you agree or disagree with the following statements on a scale of 1 to 5; $1=$ strongly disagree, $5=$ strongly agree." "Change" indicates the difference between the end-of-program survey result shown and the incoming participant survey result for that year.

${ }^{a}$ Not applicable.

studies. In some cases, the program may serve as a reality check to make them reevaluate their educational goals.

On departure and on the follow-up survey, additional questions are asked.

- What was the best part of the program?

- What part of the program shows the greatest need for improvement?

- What was the best part of the ethics component? The worst?

- What other ethical issues in engineering should the group take up in addition to those we discussed?

Some comments on the best part of the program were

- One of the best parts of this program is seeing how real research is conducted and reported.... The ethics discussions were also interesting and insightful.

- I think the best part was that for the most part, this project was independent.

- I learned that I really enjoy doing research-but more important, it revived my interest in structural engineering and helped me pinpoint specifics in the field.

Recommendations for improvement addressed faculty availability and project selection, among other issues. Based on evaluation of the 1999 results, the following changes were made for the summer of 2000 and future years.

\section{Faculty Availability}

Most UAB faculty are on nine-month appointments and spend summers in research or consulting, with limited teaching responsibilities. As a result, some faculty members were less available to the students than others. Assigning two students per faculty member did not work as well as anticipated. Some could have handled three, while others should have had one at most. Only one or two faculty per summer are supported by the program. Changes to improve faculty availability were

- Distribute three students to faculty who have enough projects available, rather than automatically placing two with each.

- Have more graduate students available to help students.

\section{Project Selection}

It is challenging to develop a suitable nine-week undergraduate research project, particularly with limited information about participants' talents and interests. Nevertheless, this is important if the students are going to produce publishable results and achieve the satisfaction of seeing a complicated project through to completion. Changes to improve project selection were

- Projects and student interests will be classified as laboratory/ field, analytical/modeling, or literature review/report to make it easier to find an appropriate match.

- Earlier recruiting might enable faculty advisors to correspond with students about the projects in advance. In practice, the faculty advisors are generally too busy to correspond with the students before they arrive.

\section{Laboratory Involvement}

Only one of the summer of 1999 projects involved extensive laboratory work. Several of the participants indicated that they would have liked to have had more laboratory experiences. Changes to address this concern were

- More projects offered in the laboratory/field category. Five students in 2000 and three in 2001 had projects in this category.

- All participants would have the opportunity to perform a few days of testing in the structures laboratory if desired, even if that is not a primary focus of their project.

A six-month follow-up survey of 1999 program participants produced results similar to those of the exit survey. Some of the comments from the follow-up survey are listed next.

- The (ethics) cases that were discussed were very interesting and provided insight on issues that we as practicing engineers want to be aware of.

- Overall, I think the program was a success.... This program improved my research skills tremendously.... The research topics were fairly interesting - some more difficult than others, but nevertheless a great learning experience for all. 
- The program was a great help to me. It took away the mystique I had as an undergraduate that graduate work and research were perhaps out of the range of my capabilities. Since attending the program I have decided to continue on to a master's degree directly after graduation.

The 2000 program featured better matching of faculty to students, better project selection, and laboratory and field-testing projects for more than half of the participants. As a result, suggestions from the 2000 program evaluation were primarily administrative. Pairing two students for a labor-intensive laboratory or field project worked well, and this arrangement will be used in the future when appropriate. In the program described by Teller and Gates (2001), students are grouped to reduce the load on supervising faculty.

\section{Summary and Conclusions}

The UAB REU site in structural engineering has been highly beneficial for the department and the participants. The student work has enhanced the breadth and depth of research under way at the host campus, and has paved the way for expansion into new areas of research for faculty. Survey results have consistently shown that participants consider this a valuable and useful experience. Many of the past program participants have gone on to graduate school at UAB or elsewhere. Three prior participants were employed full time as graduate research assistants at UAB during the 2000-2001 academic year.

The survey results indicate that the first five objectives have been met. The sixth, that of having students produce publishable work, has proven difficult because the majority of the students are just beginning to analyze the results when the project ends. However, the failure case studies have shown the potential to produce publishable papers (Martin and Delatte 2000, 2001), because the projects are well defined, students can grasp them quickly, and the UAB library has acquired extensive holdings in this area.

The seventh objective also has only been met in part. The program has been highly successful for keeping qualified UAB students for graduate school. To date, none of the REU participants from other schools has come to UAB for graduate work. A number have gone on to graduate school at other institutions, often for geographical reasons. It has been possible to informally track the students who continue on to graduate school because they almost always contact their prior faculty sponsors for recommendation letters. It also appears that the research skills that they have learned at the site have made them more competitive for better-known graduate programs. The favorable economic conditions for graduates with bachelor of science in civil engineering degrees during this period may have also played a role.

The program also requires a considerable investment by the department. The NSF funds one and a half months of faculty time and no staff time; remaining costs must be borne by the host institution or by other external grants and contracts. Considerable time must also be invested by faculty to get the students started on their projects.

\section{Acknowledgments}

The UAB REU site in structural engineering has been supported by the National Science Foundation under Grants EEC 9531691 and 9820484. Participating faculty and staff, including Duane Castaneda, Harold Kincaid, Fouad Fouad, James Davidson, Shen-en Chen, David Olowokere, David Newman, Richard Hawkins, and Mischell Massey, have been instrumental in the success of this program.

\section{References}

Delatte, N. J. (2000). "Using failure case studies in civil engineering education." Forensic Engineering, Proc., 2nd Forensic Congress, ASCE, Reston, Va., 430-440.

González, C. (2001). "Undergraduate research, graduate mentoring, and the university's mission." Science, 293, 1624-1626.

Martin, R., and Delatte, N. J. (2000). "Another look at the L'Ambiance Plaza collapse." J. Perform. Constr. Facil., 14(4), 160-165.

Martin, R., and Delatte, N. J. (2001). "Another look at Hartford Civic Center Coliseum collapse." J. Perform. Constr. Facil., 15(1), 31-36.

Mervis, J. (2001). "Student research: What is it good for?" Science, 293, $1614-1615$.

Narayanan, R. M. (1999). "Use of objective-based undergraduate research project experience as a graduate student recruitment tool." $J$. Eng. Educ., 88(3).

Teller, P., and Gates, A. Q. (2001). "Using the affinity research group model to involve undergraduate students in computer science research." J. Eng. Educ., 90(4). 